\title{
School Choice: Shaping Personal, Family and Social Imaginaries in an Era of Neoliberalism
}

\author{
Lawrence Angus \\ University of Ballarat, Australia
}

\begin{abstract}
The paper provides a critique of 'school choice' research, which is particularly relevant for Australia where 'choice' of school is strongly advocated by government. The promotion of choice, along with policies of market competition in education, the commodification of schooling, and rigid accountability policies that require the publication of national, standardised test result, illustrates the extent to which neoliberal education policies have been adopted in Australia. The paper argues that more holistic research on school choice needs be centred on processes of choice-making within the powerful political context of neoliberalism and in relation to the aspirations and imagined futures of students, parents, teachers, schools and communities. Such research must also acknowledge and understand that, as key elements of the neoliberal world view (such as competition, choice and high stakes accountability) are normalised in the day-to-day practices of schooling, the norms and values that characterise not only our education system, but also our society and democracy, are also affected.
\end{abstract}

\section{Introduction}

A problem with much of the research on school choice is that it tends not to be conceptualised as a global phenomenon [1]. The research tends not to be linked to the major issues of globalization because school choice is regarded as an issue of the local dynamics school competition to attract sufficient, and sufficiently able, students from within the localities in which educational institutions are struggling with each other to maintain and improve their viability and market position [2]. School choice, within the education policy apparatus of virtually every western country [3], is seen to be a good thing per se because it forces schools to improve their standards and meet prescribed targets if they are to attract parent-consumers of the educational product they are offering to the local market. But the effects of school choice are much broader than this because the 'global neoliberal consensus', as Kelly puts it, 'dictates that states should be competitive abroad and facilitate a favourable pro-choice regulatory framework at home' [4]. As a consequence, state institutions and public administration has over the past three decades been put on a quasi-market footing in keeping with governance themes of economic efficiency, competition and accountability. An important element of this consensus is that schools and other providers of services need to be responsive to market discipline and adopt an enterprising approach in response to the expectations of clients that entrusting their children to them will be a worthwhile investment. Schools, therefore, need to be seen to be successful as judged by their performance in the competition of high-stakes accountability. It is within this global neoliberal consensus that, at the local level, enterprising and aspirational schools engage in impression management to signal their 'distinctiveness' in comparison with other schools [5]. They are competing to be chosen.

It is within this wider framing that researchers need to examine the centrality of 'school choice' within education policy in particular jurisdictions like Australia, and, in particular, to investigate the choice-making of students and their parents. Such research needs to investigate the extent to which parents and students are satisfied with the school choices they make. The objective would be to gain understanding of:

- how parents and children determine which schools are more or less desirable,

- how such determinations connect with

various forms of school representation,

- how school choices are related to parent and student aspirations and identity,

- the emotional burden, complexities and dilemmas of school choice-making,

- how parents and children assess their school choices on the completion of schooling.

'Choice' is possibly the key element of the Australian education policy framework and of the neoliberal policy complex in general. The particular importance of choice and market arrangements has been highlighted in Australia recently by the introduction of the My School website [6], which allows comparison of the performance of Australian schools on various indicators, including standardised tests, particularly of literacy and numeracy. This has become a critical means of benchmarking school 'quality', and such is the importance of obtaining 
good scores on such tests that schools often resort to various devious tactics to fabricate their results and their images [7]. At a time of steady drift away from government to private schools in Australia, understanding how various families and communities perceive the desirability of particular schools and make their choices about them is essential to debates about the nature and purpose of schooling and the place of comprehensive schooling in Australian society.

The policy direction in Australian education has, increasingly since the 1980s, reflected neoliberal economic and political thinking [8] which privileges the private sector over the public sector, and assumes that market arrangements will always produce better outcomes than government regulation. Hence the incorporation into education policy of competition between schools to attract clients. And because parents need a seemingly objective basis on which to make informed choices about 'good' or 'bad' schools, a regime of highstakes tests and other accountability requirements, against which schools must report their results, has been introduced.

There now seems to be complete agreement between the main political parties in Australia on the promotion of school 'choice' and strict accountability and reporting measures. Prime Minister Gillard maintains the My School website has opened up a new era of transparency that will enable parents to make informed school choices. $M y$ School illustrates the extent to which the neoliberal policy framework emphasises market arrangements, centralised testing regimes, publication of test results, strict school and teacher accountability procedures, centralised curriculum and standards, and a managerial approach to educational governance. Under such conditions of 'transparency' and 'quality control', it is assumed, market discipline and consumer choice will promote conditions of self-improvement such that schools will continually strive to out-perform each other. This is seen as necessary to drive up standards and to drive the economic competitiveness of the country. Such policies, all of which are consistent with the global neoliberal consensus, have therefore imposed a very powerful disciplinary template over schools in Australia and elsewhere.

\section{The literature on 'school choice' and neoliberalism}

'School choice' has become a (possibly the) central plank in what is often referred to as a neoliberal education policy complex that has become entrenched in many counties, particularly English-speaking countries, over the past 20-30 years [9]. The origins of this policy framework are usually identified as being the government of
Margaret Thatcher in the UK in the early 1980s, although somewhat similar policies were pursued in the USA at the time during the presidency of Ronald Reagan [10]. Direct policy borrowing from the UK was evident in New Zealand in the late 1980s [11] and soon afterwards in Australia [12]. The policy direction in Australian education, and in the public sector, has increasingly emphasised notion of markets and consumer choice. Hence the incorporation into education policy of competition to attract clients between schools, in both the government and non-government sectors. Because parents need a seemingly objective basis on which to make informed choices about 'good' or 'bad' schools, a regime of high-stakes tests and other accountability requirements, against which schools must report their results, has been introduced [13].

Within the performative and regulatory regime that seems now to have become taken for granted, the edicts of the neoliberal global consensus have been incorporated into national education legislation and regulation which has effectively brought education systems into the service of the global economy. The aim is that through policies of competition and choice education will become increasingly more productive and the economy more competitive and successful. As Moutsios summarises this argument, the power of education policy lies in 'the increasingly global acceptance of a specific perception of what education should be about: to maintain or increase "economic competitiveness" or "growth" or "development" or, ultimately, "progress”' [14]. As Moutsios goes on to argue:

The prevalence of policy-making at both national and transnational levels, through managerial bureaucracies, should be taken in conjunction with economic globalization, which dedemocratises decision-making processes, as a number of studies have remarked. Indeed, globalization entails that important decisions for societies are taken within transnational economic and political networks rather than by national or local institutions of representation and certainly not by their citizens.... As a consequence, education politics as the activity of teachers/academics, learners and parents to question and reflect the purpose, the contents and the pedagogic mode of learning, is superseded by transnational policy-making, which aims primarily at generating the cognitive and human resources required by labour markets [15].

So successful has this move been that conceptions of fundamental notions like education, and even democracy, have been refashioned. Within the politics of marketization, as Kelly puts it, the assumption that is continually endorsed is that 
'democracy flourishes best in a competitive market economy with minimal state intervention, and emphasises individual [economic] freedom at the expense of the social collective' [16]. Widespread acceptance of this specific conception of the purpose of education. and of who should benefit from education, has become largely entrenched. At its most fundamental level:

[U]nder the conditions of neoliberal globalization, capitalist criteria and values are incorporated into what is defined and what is measured as progress of societies and they are expressed in education policies across the world through the reform agendas of transnational institutions [17].

This way of looking at the world has become seemingly naturalised, and issues of student engagement at the local level are now caught up in performative regimes as schools try to demonstrate that they meet and exceed mandated standards and high stakes tests. All of this does symbolic violence to alternative educational ideas and imagined educational futures that might be built along inherently 'educational' rather than economic and competitive lines.

There now seems to complete agreement between the main political parties in Australia on the promotion of school 'choice' and strict accountability and reporting measures for schools. The commitment of the current Federal government to such policies is demonstrated by the introduction of the My School website. At the recent re-launch of the website, Education Minister Garret stated on 4 March, 2011, that: 'As a government we recognise how important it is that ... we understand how our students are performing, and that, particularly, we enable parents to get the information they need to make the kind of decisions and choices [about schools] they have to make' [18]. By 7 March, 'league tables' ranking schools on the basis of their My School results had been published in various newspapers including The Canberra Times, NT News, Herald Sun and Sydney Morning Herald [19]. Competition between schools and individuals is seen as necessary to drive up standards and to drive the economic competitiveness of the country. Notions of individualism, commodification and market have led to poor student performance being represented as the responsibility of schools rather than the sociopolitical, cultural and economic factors that affect school performance [20]. Policies of 'choice' and 'high-stakes' testing press schools to perform well in order to market their wares in the competitive environment, and parents are encouraged to access all available information to assist them to be discriminating in making sound choices about which schools are appropriate for their children.
Such decision-making by parents and students about school choices needs to be examined through direct research not only with families in the process of selecting schools but also with families whose children have completed their schooling. Parents and children would be asked to explain their choices and their decision-making, and their aspirations and expectations. Parents of children who have completed school, and the children themselves, would be asked about their experience of the school they chose compared to their expectations. This qualitative approach would provide rich insight into how a diverse range of families make sense of the representations of a variety of schools, their choicemaking about particular schools, and how their experience of their preferred school (as parents and students) compares to their expectations. Particular attention would be given to how schools are understood as 'good' and 'bad', and the strategies used to gain access to preferred schools.

Despite the ubiquitousness of school choice policies and their application to all forms of schooling, the international literature would suggest that it tends to be middle-class families - those with sufficient 'family capital' [21] to take advantage of the opportunities school choice policies offer, or with sufficient 'parental imaginary' [22] to envisage the potential benefits of changing schools - who attempt to improve the social advantages of their children through the 'choice' mechanism [23]. Certainly, most of the literature on 'school choice' in Australia to date has been mainly concerned with the decision-making of middle-class parents about whether to send their children to non-government schools, particularly 'private' schools. A recent example of such research is that reported by Campbell and others [24], which deals particularly with the anxieties of middle-class parents trying to choose the 'best' non-government schools for their children. Such identification of 'school choice' with the increasing patronage of non-government schools is quite common in the Australian literature, where the term 'school choice' tends to be associated with the policies of political parties, particularly the Liberal Party, to subsidise non-government schools in order, ostensibly, to make them more accessible to a greater number of families [25]. However, school choice is now a major consideration for students and their parents of all social classes, although the choosing is influenced by indirect as much as by direct factors.

In terms of the broader effects the of school choice policies on localities, societies and even globally, it is important to remember that the immediate realities of any individual choice-making are influenced by the entire educational context throughout which the pervasiveness of choice, market and accountability factors bear down upon, and shape, the ways in which students, parents, 
teachers and communities engage with local schools. The dynamics of any particular school are framed by the policy/regulative environment and are affected by every other school and by the market situation which is prevalent across all schools. The resonance of school choice is having a profound impact on the kind of education provided by all schools, not just in Australia but internationally. Any adequate research, therefore, should of necessity investigate the full spectrum of schools and society in relation to parent choice-making about the relative desirability of schools. Indeed, the neoliberal policy position is that all responsible parents must vote with their feet in the consumer market that has been created in education. This is the clear intention of the Australian My School website, which suggests that the pursuit of school choice for all is 'more advanced in Australia than in any other country' [26]. And, of course, if parents are encouraged to choose schools from the full market range, schools must respond by representing themselves in the market-place as sufficiently desirable to be worth choosing. The images they present must connect with various parental imaginaries and their aspirational objectives. While performance indicators that are published, in Australia on the $M y$ School website for example, will no doubt be useful in differentiating among schools, such data is not sufficient to enable schools to stand out from their competitors. To be successful in the market, schools cannot allow themselves to be perceived as 'ordinary' [27] so they must represent themselves as being successful, distinctive, and desirable to particular market segments.

The most desirable market segment, from the point of view of aspirational schools, is most likely to be students from middle-class families who have a record of gaining high marks that enable them to enter prestigious university courses. The link between university education and economic and social wellbeing has been shown time and again to be very strong. In Australia, students from private schools enter universities at a much greater rate than students from government schools, an unbalanced outcome that reflects a segregated society in which high SES students are three times as likely as low SES students to enter university. Throughout Australia there has been a prolonged, gradual shift to private schools and increasing competition for places at high-performing government schools. It is not surprising, therefore, that school choice-making creates anxiety for parents. [28]. Within a context of increasingly aggressive marketization of schooling and an intensified demand within the workforce for higher education qualifications, the responsibility of choosing a school for one's children can be onerous. Many opt for high-performing government schools but the demand for places in these greatly exceeds supply, in which case it is the schools that are able to do the choosing. In a perverse twist on the usual provider-consumer relations of the market, prospective students must demonstrate their worth and be marketed to the school.

While, for private schools, substantial fees tend to ensure that only middle-class candidates are admitted, some government schools employ unofficial, often covert, selection mechanisms in attempts to protect or improve their academic standing. Some are widely known for their excellent results and are notoriously difficult for prospective students to access. High demand for entry is managed through a complicated mix of zoning, examination-based entry into accelerated programs, and specialised curriculum pathways. The popularity of these schools has contributed to increases in property prices within their zones as aspirational parents seek to buy houses there so their children will qualify for entry [29]. The outstanding results of students who attend such schools enable some of them to compete favourably with the highest performing private schools. Similar jockeying for positions in 'good' government schools occurs nationally and internationally. Clearly, middle-class parents have the greatest capacity to exercise choice within both the nongovernment and government sectors. Because of their financial and cultural resources, and because they are sufficiently education-literate to compose the sort of applications that will gain their children places at desirable government schools [30], such parents sometimes employ tutors to coach their children to sit entry examinations for accelerated programs or select entry schools. They are likely to ensure that their children learn musical instruments or gain other cultural or extra-curricular experiences to signal to prospective schools their worthiness as students who have the capacity to successfully complete Year 12. The following statement, made by a mother who planned her daughter's entry into a high-performing government school over many years, illustrates the technique:

I was determined to get my daughter in. I went to every Open Day starting in Years 4, 5 and 6. I still go. It took me two years to get her in. Open Day is always crowded with people hanging outside the Hall. I always go early to get a seat. She always understood the expectation that we wanted her to go to Leafy Suburbs College. She had a letter from the principal of her primary school urging her acceptance at Leafy Suburbs College. We advised her to play an instrument other than flute, which is too popular and not as well weighted as other less popular instruments such as the oboe [31]. 
Students from aspirational middle-class families are the most likely to be considered good prospects for schools, and, to a large extent, the 'successful' schools are invariably those that are able to attract and retain middle-class students. It is the nature of its intake that largely defines the reputation of a school. Some literature also refers to 'white flight', particularly in the USA, where schools with high enrolments of minority students are likely to be shunned by white, middle class parents, adding a further dimension to the polarisation of school communities [32]. The obverse of this phenomenon is that of 'gentrification' of inner-city areas, which tends to displace low SES populations [33]. The assumptions that are built in to education policies, therefore, have the effect of reinforcing privilege. Against the backdrop to any localised choosing is the collection of performance statistics that enable particular schools to claim that they are high achieving. A wide range of educational options is clearly available to middle-class parents and the school choice environment typically reinforces the social advantages available to this class through education. However, working-class parents and students with limited resources are typically assumed to exercise little if any choice, and such parents and their children have not featured largely in the literature on school choice. Overwhelmingly, the literature reveals that middle-class parents possess both the cultural and financial advantages to operate within the school choice and testing environment to ensure their own children's social and educational advantages are preserved. However, the assumption that only middle class parents exercise choice may be misleading in its implication that poor people do not understand the link between schooling and upward social mobility. The more salient point may be that members of working class families are not advantaged by the seemingly neutral assumptions that, as I have discussed above, make the passage into schools with good reputations relatively easy for most middle class students [34], whose parents, and whose social capital, comfortably gel with the central concept of school choice, namely that the parent is a consumer. Working class parents are less likely to feel comfortable or familiar with such consumerist logic. Good parental choosing, as well as good educational attitudes, aspirations and performance, is constructed in keeping with implicit middle class norms. For many working class students, the level of cultural dissonance they encounter in many schools is such that they feel so alienated that they are unlikely to make the active choice of trying to succeed in a school that seems somewhat like a foreign country in which they, their families and the people they know seem like outsiders who are not valued and respected. For them, choosing educational success may mean choosing to become a different person, as Ball explains:

The risks and reflexivity of the middle classes are about staying as they are and who they are. Those of the working classes are about being different people in different places, about who they might become and what they must give up [35].

In this sense, education can be regarded as 'classing up', or forgoing one's working class identity [36]. By 'classing up', they become different people and occupy different places to their parents. Their imagined futures and 'new' identities may conflict with the 'old'. School choice can therefore polarise schools, families and communities, so there is an urgent need to consider how some schools gain reputations for excellence or failure, and to determine whether such reputations are real or imagined, earned or fabricated. This point about identity is crucially important because, as Lee and Anderson explain, it is difficult for such young people to form a new educational identity:

In the educational contexts, questions of identity are especially critical because the development of educational practice and policies is grounded in different ways of understanding who learners are or should be. How students interpret and develop their identities in a given context is shaped by self-perceptions, desires, hopes and expectations as well as the salient aspects of social context, such as sociopolitical ideologies, histories and structures that are often beyond the control of an individual [37].

In the prevailing rhetoric of school choice, competition and performance, however, educational success is assumed to be the product of natural merit and careful choosing, not social privilege.

\section{A research agenda}

In the light of the discussion above, it would seem imperative for researchers into schoolchoosing to gain insight into the emotional work of trying to deal with the complexity and implications of school choices. Research needs to regard the making of such choices as emotionally complex and far from simple; particularly for non-middle-class families whose social and cultural capital is less likely to be congruent with the consumer norms and assumptions about education that currently prevail. Understanding how parents and children make choices, and the positive and negative effects of their choices in practice, is clearly significant and important and is connected to the ways in which they have previously interacted with schools. For 
working class families, such interaction has generally not been from a position of strength, unlike the typical experience of middle-class families. Such variable engagement raises questions of culture and identity. A great deal of research since the 1970s has shown that 'the cultural habits brought to school by significant proportions of students are not utilised or scaffolded to traditional school learning methods and contents.... Rather, their lack of fit with the culturally arbitrary selections that are valued by school becomes individualised and internalised as "failure" [36]. The important point here is that in envisaging different possible selves, which is necessarily a social and embodied process, not an individual one, students from advantaged families are much more likely than working class students to think about a possible future self who is educationally successful.

Choice and market arrangements in Australia, as highlighted by the introduction of the My School website, have become a critical means of benchmarking school 'quality', and such is the importance to schools and to individual students and parents of obtaining good scores on such tests that, according to the international literature, many schools have resorted to various devious tactics to fabricate their results and their images [39]. At a time of steady drift away from government schooling, understanding how various families and communities perceive the desirability or not of particular schools, and make their choices about them, is essential to debates about the nature and purpose of schooling and the place of comprehensive schooling in society.

Researchers need to capture how school choicemaking is responsive to time and place, and to shed light on opportunities, strategies and capacities for choosing that may differ within and between particular families and communities. The ways in which school choice engages with forms of social imaginary is essential to various notions of the 'good' and 'bad' school that are promulgated through school league tables and various other school representations. As Taylor [40] defines this notion of 'social imaginary':

What I am trying to get at with this term is something much broader and deeper than the intellectual schemes people may entertain when they think about social reality in a disengaged mode. I am thinking rather of the ways in which they imagine their social existence how they fit together with others and how things go on between them and their fellows, the expectations that are normally met and the deeper normative notions and images that underlie these expectations.
Taylor explains that a social imaginary has several important elements. It relates to the way 'ordinary people imagine their social surroundings', not in a theoretical sense but in terms of an imagined, future reality which is understood for the present as depicted in images, dreams and stories; it is shared by large groups of people; and it provides a set of common understandings that are tightly 'interwoven with an idea of how [things] ought to go' [41] and which therefore confirm certain ideas and practices as legitimate. A social imaginary, therefore, is socially constructed, widely shared, and has a tremendous pedagogical effect on populations in legitimating what is regarded as normal, natural and appropriate. It influences how people think about the nature and scope of government and social institutions like education. The point I have been making throughout this paper is that indulging in school choice is participating in the construction of a social imaginary.

The most powerful and dominant social imaginary in the current historical period, according to Rizvi and Lingard [42], is 'the neo-liberal imaginary', the dominance of which in education policy is the subject of their book. These authors explain the emergence in education of the various elements of neoliberalism into a relatively coherent set of discourses and practice in which large numbers of the general public 'imagine their social existence'. The task for educational researchers is therefore to problematize and 'reimagine' the neoliberal imaginary and consider more desirable and educationally appropriate alternatives that would not discriminate in favour of the middle-class families who are already advantaged by the education system. It might be appropriate for such researchers to think about a 'socially democratic imaginary' as an appropriate, educative, and socially just alternative.

The analysis of the subtle effects on people, schools and society of school choice policies needs to draw out the identity implications of school choices through an examination of families' aspirations and expectations, their family capitals, their social imaginaries and their estimation of whether these are likely to be met by their schools and the ways in which they relate to them. Of course, identities and imagined futures are never static. They are continually emerging in relation to social contexts and life experiences. Shifts in one's sense of self and sense of one's possible future occur as a result. The identity implications of such meaning making must be considered in relation to affect - the feelings, emotions and sense of self that are invoked through being a player (or not) in the school choice game, or through gaining or not gaining a place in a particular school, or through the sense of emotional self that comes from being associated with a particular school (or not), or 
finishing school with the desired results (or not), or being excluded from a particular school. It is affect that brings families and schools together through the acceptance or rejection of students and through the facilitation of aspirations that have implications for young people's sense of self and their imagined future lives.

Representations of secondary schools would need to be explored using sites such as My School, school websites and brochures, community press reports, etc. The aim would be to understand how schools represent themselves, how such representations connect with the imaginations of students and their families, and how the schools are represented in local discourses, local media or on $M y$ School, for example. Particularly important would be the extent of overlap and/or divergence between the ways schools represent themselves and the ways in which they are perceived, not only by students, potential students and their families, but also by school staff members and members of neighbouring schools. Equally important is the extent to which 'desirable' schools conform to elements that are significant in current educational policy terms. A specific aspect of this last point, in Australia at least, would be the extent to which the My School website is seen to be influential.

\section{Conclusion}

Current Australian education policy is based on the fundamental assumption that an educated population is necessary for national economic competitiveness. 'School choice' is considered the essential ingredient in prompting schools to compete for students. This, it is assumed, will drive schools to become self-improving and, in turn, will increase Australia's national economic competitiveness. This is regarded as an important equity issue, as well as an issue of school improvement, because increasing participation in higher education is both a national priority and a priority for families who link the choice of school to potential life chances. The national emphasis is reflected in Australia's higher education enrolment target for young people of low SES backgrounds (20\% by 2020). This target is unlikely to be achieved without a substantial increase in school completions and transfers to higher education. Research into school choice, therefore, could provide a way of engaging with debates about the place of comprehensive schooling and education market policies in Australian society at a critical time in its history. Faith in a school system that provides all students with a reasonable measure of educational opportunity is vital to the social health and wellbeing of Australia as well as to its economic wellbeing. Strengthening Australia's economic and social fabric will require a school system in which educational success is possible for all regardless of their socioeconomic background. The current arrangement does not seem to deliver on this expectation.

School choice is no longer merely a matter of parents and children calmly thinking about the schools on offer and deciding upon what school seems best. In the neoliberal world in which markets are privileged, choices are actively shaped not only by particular schools marketing themselves, but also through the pervasiveness of the neoliberal imaginary. By this I mean the consolidation in education of the various elements of neo-Vliberalism into a set of discourses and practices which, as illustrated by the prominence given to the My School website in Australia, cohere around concepts of competition, market, accountability and choice. Although this imaginary is socially constructed, it is widely shared and has a tremendous pedagogical effect on the general public in legitimating what is regarded as normal, natural and appropriate in educational governance and in society at large. It influences how people think about the importance of self-interest within their own lives and in the competitive global world. This topic is huge and any research that attempts to deal with it would have to be rendered manageable through strategic data collection that would enable insight into the extent to which the neoliberal imaginary has overwhelmed other possible imaginaries that might be considered more 'educational' and socially democratic.

The theoretical framing of this paper has employed a number of interrelated conceptual tools - social imaginary, spatiality, identification, representation, and affect - which may be able to inform an innovative and contemporary engagement with the social and spatial contexts of school choicemaking. The meanings uncovered would have been negotiated within particular spaces at critical times because they have consequences for individuals, families and communities who may be struggling to understand who they are and who they want to become.

\section{References}

[1] A. Kelly, "Globalization and education: a review of conflicting perspectives and their effect on policy and professional practice in the UK”, Globalisation, Societies and Education, 7(1), 2010, pp.15-68.

[2] S. Gewirtz and S. Ball, "From 'Welfarism' to 'New Managerialism': Shifting discourses of school headship in the education marketplace, Discourse: Studies in the cultural politics of education, 21(3), 2000, pp.253-268).

[3] L. Angus (2011): “Teaching within and against the circle of privilege: reforming teachers, reforming schools”, Journal of Education Policy, DOI:10.1080/02680939.2011.598240. 
[4] A. Kelly, op. cit., p.54

[5] M. Maguire, J. Perryman, S. Ball and A. Braun, “The ordinary school - what is it?”, British Journal of Sociology of Education, 32(1), 2011, pp. 1-16.

[6] http://www.myschool.com.au/ (accessed 20 December, 2011)

[7] R. Barrett and J. Minus, "Students 'told to stay home' from NAPLAN tests”, The Australian, May 12. 2010; M. Maguire, J. Perryman, S. Ball and A. Braum, "The 'ordinary' school - what is it?" British Journal of Sociology of Education, 32 (3), 2011, pp. 1-16; D. Ravich, The death and life of the great American school system: How testing and choice are undermining education, Basic Books, New York, 2010.

[8] M. Pusey, Economic Rationalism in Canberra: A Nation-Building State Changes its Mind, Cambridge University Press, Cambridge, 1991; T. Seddon and L. Angus (Eds.), Beyond nostalgia: Reshaping Australian Education, Australian Council for Education Research, Melbourne, 2000.

[9] R. Alexander, Children, their world, their education: Final report and recommendations of the Cambridge Primary review, Routledge, London, 2009; L. Angus "Globalization and educational change: Bringing about the reshaping and re-norming of practice", Journal of Education Policy, 19(1), 2004, pp. 23-42; S. Ball, Education policy and social class, Routledge, London, 2006; L. Darling-Hammond, The flat world and education: How America's commitment to equity will determine our future, Teachers' College Press, New York, 2010; B. Lingard, "Policy borrowing, policy learning: Testing times in Australian schooling”, Critical Studies in Education, 51(2), 2010, pp. 129-147.

[10] S. Klees, "A quarter century of neo-liberal thinking in education: Misleading analyses and failed policies", Globalisation, Societies and Education, 6(4), 2010, pp. 311-348.

[11] M. Thrupp, "School-level education policy under New Labour and New Zealand Labour: A comparative update”, class parents, identities, educational choice and the urban comprehensive school: ambivalence and moral ambiguity, British Journal of Sociology of Education, 29 (3), 261-272. 2008)

[12] L. Angus, and L. Brown, Becoming a School of the Future: The micro-politics of policy implementation, Apress, Melbourne, 1997; L. Angus and T. Seddon, 'The social and organisational re-norming of education”, pp. 151-169, in: L. Angus and T. Seddon (Eds.) Beyond nostalgia: Reshaping Australian education, ACER, Camberwell, Vic, 2000.

[13] L. Angus, L. "The politics of community renewal and educational reform: School improvement in areas of social disadvantage”, pp. 204-220, in E. Samier (Ed) Political Approaches to Educational Administration and Leadership, New York: Routledge, 2009.
[14] S. Moutsios, "Power, politics and transnational policy-making in education”, Globalization, Societies and Education, 8(1), 2010, pp. 121-141.

[15] Ibid,. pp. 126-127.

[16] A. Kelly, op. cit.

[17] S. Moutsios, op. cit., p. 136.

[18] The Age, Melbourne, 4 March, 2011.

[19] The Age, Melbourne, 8 March, 2011.

[20] L. Angus, op. cit.

[21] Kirk, C., Lewis-Moss, R., Nilsen, C. and Colvin, D. "Expectations on adolescent educational aspirations", Educational Studies, 37 (1), 2011, p.90.

[22] E. Yoon and K. Gulson, "School choice in the stratilingua city of Vancouver", British Journal of Sociology of Education, 31(6), 2010, p. 707.

[23 C. Vincent, S. Ball and S. Kemp, "The social geography of childcare: Making up a middle-class child", British Journal of Sociology of Education, 25 (2), 2004, pp. 229-224; X. Wu, "Power of positional competition and market mechanism: An empirical study of parental choice of junior middle school in Nanning, PR China”, Research Papers in Education, 26 (1), 2011, pp. 79-104.

[24] C. Campbell, H. Proctor and G. Sherington, School choice: How parents negotiate the new school market in Australia, Allen \& Unwin, Crows Nest, NSW, 2009.

[25] J. Smyth, B. Down and P. McInerney, 'Hanging in with kids' in tough times: Engagement in contexts of educational disengagement in the relational school, (New York, Peter Lang).

[26] http://www.liberal.org.au/Issues/Education.aspx (accessed 20 December, 2011)

[27] M. Maguire et al., op. cit.

[28] G. Tsolidis, Youthful Imagination, Schooling, subcultures and social justice, Peter Lang, New York, 2006; C. Campbell et al., op cit.

[29] C. Campbell et al., op. cit.

[30] G. Tsolidis, op. cit.

[31] quoted in G. Tsolidis, op. cit., p.

[32] G. Crozier, D. Reay, D. James, F. Jamieson, P. Beedell, S. Hollingworth and K. Williams, "White middleclass parents, identities, educational choice and the urban comprehensive school: ambivalence and moral ambiguity, British Journal of Sociology of Education, 29 (3), 261272; C. Paechter, "Metaphors of space in educational theory and practice", Pedagogy, Culture and Society, 12 (3), 2004), pp. 449 -66. 
[33] P. Lipman, "Education and the spatialization of urban inequality: A case study of Chicago's Renaissance 2010", pp. 283-322, in: K. Gulson and C. Symes (Eds.) Spatial Theories of Education: Policy and Geography Matters, RoutledgeFalmer, London, 2007.

[34] S. Ball, J. Davies, M. David and D. Reay, "Classification' and 'Judgement': Social class and the 'cognitive structures' of choice of Higher Education”, British Journal of Sociology of Education, 23 (1), 2002, pp. 51-72.

[35] Ibid, p. 69

[36] L. Angus, “The politics of community renewal and educational reform: School improvement in areas of social disadvantage”, pp. 204-220, in: E. Samier (Ed.) Political Approaches to Educational Administration and Leadership, Routledge, New York, 2008; J. Smyth, L. Angus, B. Down and P. McInerney, Critically engaged learning: Connecting to young lives, Peter Lang, New York, 2008; J. Smyth, L. Angus, B. Down and P. McInerney, Activist and socially critical school and community renewal: Social justice in exploitative times, Sense Publishers, Rotterdam, 2009.

[37] quoted in C. Raffo, "Educational equity in poor urban contexts - exploring issues of place/space and young people's identity and agency”, British Journal of Educational Studies, 59(1), 2011, pp. 1-19.

[38] C. Raffo, op. cit., p. 11.]

[39] R. Barrett and J. Minus, "Students 'told to stay home' from NAPLAN tests”, The Australian, 12 May, 2010; M. Maguire et al., op. cit., D. Ravich, "Why I changed my mind about school reform", The Wall Street Journal, 9 March, 2010.

[40] C. Taylor, "Cultures of democracy and citizen efficacy”, Public Culture, 19(1), 2007, pp. 117-150.

[41] Ibid, p. 120.

[42] F. Rizvi and B. Lingard Globalizing education policy, Routledge, New York, 2010. 